\title{
FOOD QUALITY ON THE POLISH MARKET - THREATS AND WAYS OF THEIR ELIMINATION
}

\author{
STANISŁAW KOWALCZYK \\ MARIOLA KWASEK
}

\begin{abstract}
The article is dedicated to the issue of food quality on the Polish market, identification of threats and ways to eliminate them. In the modern world, the issue of quality and related food safety is a matter of special concern for countries and international organizations. Lack of appropriate institutional solutions in the food market creates the risk of adverse effects on human health or life. Identification of risk areas throughout the food chain, i.e. from primary production through processing, storage, distribution, sale of food products to consumption, forms the basis for ensuring food safety. Based on the actual results of inspections of institutions established for official food supervision, the state of health and economic security (scale of irregularities and adulteration) of food on the domestic market was presented.
\end{abstract}

Keywords: food quality, food adulteration, food quality schemes.

JEL codes: Q18, K22, A12.

\footnotetext{
* The paper used the results of the studies of the "Food Platform" project (acronym SELLFOOD) financed by the National Centre for Research and Development under the programme entitled "Social and economic development of Poland in the conditions of globalising markets - GOSPOSTRATEG" pursuant to the Agreement No Gospostrateg 1/385521/2/NCBR/2018.
}

Stanisław Kowalczyk, PhD, DSc, ProfTit, Institute of Agricultural and Food Economics - National Research Institute, Department of Agricultural Economy, Agricultural Policy and Rural Development; ul. Świętokrzyska 20,00-002 Warsaw, Poland (stanislaw.kowalczyk@ierigz.waw.pl). ORCID iD: 0000-0002-5052-3462.

Mariola Kwasek, PhD, DSc, Assoc. Prof. IAFE - NRI, Institute of Agricultural and Food Economics National Research Institute, Department of Agricultural Economy, Agricultural Policy and Rural Development; ul. Świętokrzyska 20, 00-002 Warsaw, Poland (mariola.kwasek@ierigz.waw.pl). ORCID iD: 0000-0002-3691-1733. 


\section{Introduction}

Striving for ensuring food quality is an important part of the EU food sector strategy in the global market so as to maintain a high level of competitiveness. In order to ensure high food quality, all links of the food chain, ranging from primary production, processing, storage, distribution, sale of food products to consumption, must be strictly supervised so as to identify the factors (of biological, chemical and physical risks) reducing food quality.

In addition to the qualitative requirements, food placed on the market in the European Union, also including Poland, has to meet the food safety requirements specified in food law of the European Union. Recognising the areas of risk in the whole food chain is provides the basis for ensuring food safety.

Failure to ensure food safety poses a risk of placing hazardous food on the market, defined in legal terms as a food product whose consumption in normal conditions and in accordance with its intended use may result in adverse effects on human health or life. Recognising the areas of risk in the whole food chain i.e. from primary production, processing, storage, distribution, sale of food products to consumption provides the basis for ensuring food safety.

The level of food safety on the Polish market is good and comparable with that in other EU countries. However, it is not free from irregularities which may increase periodically. It is possible to minimise these threats, i.e. through consistent controls, promotion of participation in voluntary quality schemes and high requirements with regard to the quality standards.

\section{Level of safety and quality of agri-food products in Poland}

One of conditions of efficient trade in food products is the supply of products which are of good quality and are safe for our health. In this context, it is essential to recognise this attribute of the Polish food market.

Based on the actual results of controls carried out by institutions appointed to exercise official supervision of food, the state of health and economic security of food on the domestic market has been presented. To assess the state of health safety, the results of controls by the State Sanitary Inspection (SSI) and the European Food Safety Authority (EFSA) were used, while to assess the quality and economic security - the results of controls carried out by the Agricultural and Food Quality Inspection (AFQI).

Food safety and quality are strongly interrelated. Pursuant to the EU regulation, official controls are to apply to food, its safety, integrity, health qualities and protection of consumers' interests at each stage of production, processing and distri- 
bution of food (Article 1(2)(a)) ${ }^{1}$. Thus, they refer to both food quality, its nutritive values and consumers' interests. The very notion of food safety is, however, ambiguously defined, even within a single institution or country. Therefore, it refers both to threats resulting from food contamination and poisoning, and thus to health safety and to consequences of food fraud, including, in particular, food adulteration, i.e. to economic security of food. Therefore, it concerns issues such as: chemical, physical and microbiological food contamination, compliance with the trade and market standards, including, in particular, compliance of physical, chemical and microbiological parameters of food with the producer's declaration, sensory properties of food, and finally, irregularities taking place in all above-mentioned areas, including, in particular, those related to food adulteration ${ }^{2}$.

In turn, food quality should be defined as properties and/or characteristics of a food product. They refer to issues such as: composition, including the nutritive value of a product, production technology and method, level of its potential adulteration and/or contamination and packaging and labelling. In a nutshell, food quality can be referred to as the compliance with the producer's declaration.

In Polish food law, there is a notion of the so-called commercial quality. Commercial quality means characteristics of an agri-food product referring to its organoleptic, physical, chemical and microbiological properties with regard to the production technology, size or weight as well as the requirements resulting from the production method, packaging, presentation and labelling, not covered by the sanitary, veterinary or phytosanitary requirements (Notice..., 2017, p. 34). Therefore, commercial quality of food refers not only to the characteristics and properties of a product but also to the conditions of its production, labelling and presentation.

The non-commercial requirements in relation to food quality, including the sanitary, veterinary and phytosanitary requirements, constitute the so-called health quality of food which is presently identified with health safety of food. ${ }^{3}$

\footnotetext{
${ }^{1}$ Regulation (EU) 2017/625 of the European Parliament and of the Council of 15 March 2017 on official controls and other official activities performed to ensure the application of food and feed law, rules on animal health and welfare, plant health and plant protection products, amending Regulations (EC) No 999/2001, (EC) No 396/2005, (EC) No 1069/2009, (EC) No 1107/2009, (EU) No 1151/2012, (EU) No 652/2014, (EU) 2016/429 and (EU) 2016/2031 of the European Parliament and of the Council, Council Regulations (EC) No 1/2005 and (EC) No 1099/2009 and Council Directives 98/58/EC, 1999/74/EC, 2007/43/EC, 2008/119/ EC and 2008/120/EC, and repealing Regulations (EC) No 854/2004 and (EC) No 882/2004 of the European Parliament and of the Council, Council Directives 89/608/EEC, 89/662/EEC, 90/425/EEC, 91/496/EEC, 96/23/EC, 96/93/EC and 97/78/EC and Council Decision 92/438/EEC (Official Controls Regulation) (OJ EU of 7.4.2014, L 95/1).

${ }^{2}$ More on this subject cf. Kowalczyk (2016).

${ }^{3}$ The definition of health quality of food was specified in the Act on health conditions of food and nutrition which was repealed in 2006 by the Act on food and nutrition safety (Act of 25 August 2006 on food and nutrition safety, Journal of Laws 2006, No 171, item 1225).
} 


\section{Health safety of food}

In Poland, the level of health safety, which is determined by health quality of food, is controlled mainly by the State Sanitary Inspection (SSI) and by the Veterinary Inspection (VI) with regard to products of animal origin, at the stage of processing.

The percentage of food samples tested by the SSI and questioned due to their improper health parameters has gradually been reduced in recent years (Fig. 1).

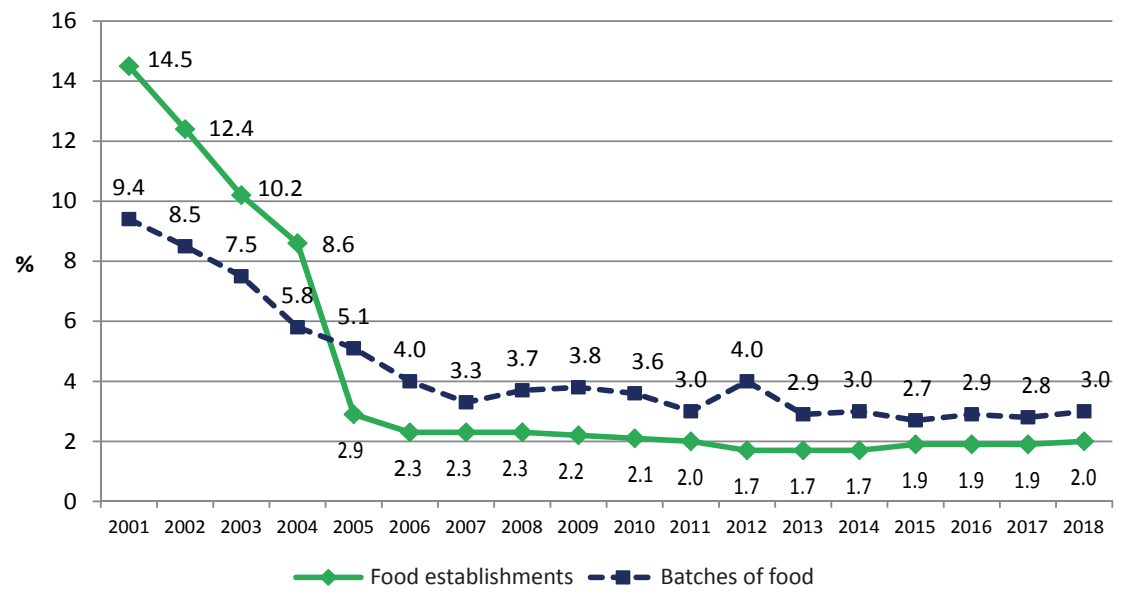

Fig. 1. The percentage of food batches with improper health quality and the percentage of food and catering establishments whose sanitary state is not compliant with the requirements in the years 2001-2018 (\%).

Source: own study based on the results of SSI controls in the years 2001-2018.

While in 2001 the health quality of food on the Polish market was questioned for $9.4 \%$ of tested samples (in 2000 , it was even $10.6 \%$, i.e. more than every tenth sample), in the year of accession to the European Union (2004) it was 5.8\% and as from 2007 this level has ranged between $2.7 \%$ and $4 \%$. In 2018, 3\% of tested food samples were of improper health quality. In the case of certain groups of food products, the level of batches whose health status was improper was, however, higher and amounted to, for example, $7.3 \%$ for milk and milk products, 5.8\% - for poultry and poultry products (Table 1 ). Here, we may identify three basic groups of products in terms of the risk of losing health safety:

- First group: with a higher level of risk (on average, twice as high) in relation to the average level in the food sector (milk, poultry, sugar), ${ }^{4}$

- Second group: with an average level of risk (meat, cereal grain, vegetable fats, oilseeds),

- Third group: with a lower level of risk in relation to the average level in the food sector (fruits, vegetables).

\footnotetext{
${ }^{4}$ Measured by the number of food batches questioned by the SSI.
} 
As shown in the above-mentioned classification, many products should be classified into the first and second groups, i.e. those with a higher or at least an average level of risk in terms of health safety. Those groups involved seven out of nine analysed groups of products. A certain improvement in this situation, visible in the years 2015-2017, referred to oilseeds only. It was definitely the best in the case of fruits and vegetables.

Table 1

Health safety of food products on the Polish market in the years 2005-2018 (in \% of questioned batches)

\begin{tabular}{lccccccccccccc}
\hline \multicolumn{1}{c}{ Products } & 2005 & 2006 & 2007 & 2008 & 2009 & 2011 & 2012 & 2013 & 2014 & 2015 & 2016 & 2017 & 2018 \\
\hline $\begin{array}{l}\text { Cereal } \\
\text { grain }^{\mathrm{a}}\end{array}$ & 4.1 & 2.4 & 3.0 & 3.0 & 3.1 & 2.2 & 5.0 & 3.2 & 2.3 & 2.5 & 1.8 & 1.7 & 2.2 \\
$\begin{array}{l}\text { Oilseed } \\
\text { grains }\end{array}$ & - & - & 6.0 & 5.7 & 4.0 & 4.0 & 2.5 & 8.3 & 2.7 & 0.4 & 0.2 & 0.4 & 1.2 \\
Sugar & 2.3 & 4.1 & 3.4 & 5.2 & 4.0 & 0.4 & - & 3.6 & - & 5.3 & 8.3 & 5.3 & - \\
Fruits $^{\mathrm{b}}$ & 3.1 & 3.9 & 2.4 & 2.4 & 1.8 & 1.6 & 2.5 & 1.6 & 1.7 & 1.4 & 0.7 & 1.5 & 1.8 \\
Vegetables $^{\mathrm{b}}$ & 3.1 & 3.9 & 1.9 & 1.5 & 2.0 & 1.2 & 1.5 & 1.4 & 1.1 & 1.6 & 0.8 & 1.2 & 1.7 \\
Milka $^{\mathrm{c}}$ & 13.2 & 5.9 & 3.6 & 4.8 & 5.0 & 4.1 & 5.0 & 4.6 & 6.7 & 6.5 & 7.4 & 7.2 & 7.3 \\
Vegetable $_{\text {fats }}$ & 1.2 & 0.6 & 0.5 & 1.1 & 1.3 & 2.3 & 2.6 & 3.0 & 3.7 & 1.4 & 1.5 & 2.6 & 0.9 \\
Meat $^{\mathrm{a}}$ & 2.8 & 3.4 & 1.8 & 3.0 & 3.9 & 2.5 & 3.0 & 2.6 & 2.6 & 3.4 & 2.5 & 2.3 & 1.7 \\
Poultry $^{\mathrm{a}}$ & - & - & 3.6 & 3.8 & 9.0 & 5.4 & 12.5 & 4.5 & 3.5 & 4.1 & 3.8 & 3.2 & 5.8 \\
Total & $\mathbf{5 . 1}$ & $\mathbf{4 . 0}$ & $\mathbf{3 . 3}$ & $\mathbf{3 . 7}$ & $\mathbf{3 . 8}$ & $\mathbf{3 . 0}$ & $\mathbf{4 . 0}$ & $\mathbf{2 . 9}$ & $\mathbf{3 . 0}$ & $\mathbf{2 . 7}$ & $\mathbf{2 . 9}$ & $\mathbf{2 . 8}$ & $\mathbf{3 . 0}$ \\
\hline
\end{tabular}

${ }^{\mathrm{a}}$ including food prepared from these products; in the years 2005 and $2006 ;{ }^{\mathrm{b}}$ fruits and vegetables were a single control group; ${ }^{\mathrm{c}}$ in the years 2005 and 2006, only drinking (liquid) milk.

Source: own study based on (SSI, Sanitary state of the country, in subsequent years).

The above-mentioned product range groups are a potential subject of transactions in the Food Platform being organised, therefore, the level of their health safety is particularly important. However this level of risk, which is higher when compared to other groups of products, is a consequence of the data aggregation method to a certain extent. While the subject of trade is to be products being a raw material for further processing (wheat, rapeseed, meat), in the case of the SSI approach, the results of controls of individual products (raw materials) have been combined with products of their processing (meat products, milk products). According to other sources (e.g. results of controls carried out by the Trade Inspection and AFQI), it results that processed products are more exposed to, at least, microbiological contamination than milk or meat at the initial stage of production. However, regardless of the data aggregation method, this means a need to carry out regular safety controls due to an even potentially higher level of risk of most product groups to be traded on the Food Platform being designed.

The exceptionally large variability of results of food safety during controls carried out by the SSI raised some doubts even in short periods (1- and 2-year-periods). 
For example, due to health safety in $2012,12.5 \%$ batches of poultry and its products (3.5\% in 2014 and $5.8 \%$ in 2018 ) as well as $2.5 \%$ of batches of oilseeds $(8.3 \%$ in $2013,0.2 \%$ in 2016 and $1.2 \%$ in 2018) were condemned. Apart from really deep potential market fluctuations of health safety, this situation can be potentially explained by the non-representativeness of tested batches of food in relation to the total market supply. However, each year the State Sanitary Inspection tests 70-80 thousand batches of products, which is a considerable quantity and the results obtained should properly reflect the actual state.

Another essential element of health safety of food is the sanitary state of food establishments and companies. To a great extent, it also determines safety of food itself. In recent years, there has been a radical positive change on the Polish market in this regard (Fig. 1). While at the beginning of the first decade of the 21 st century, reservations as to the sanitary condition and conditions of food production and trade were reported in the case of $14.5 \%$ companies, i.e. more than every seventh company in this sector, and in the first year of Poland's membership in the European Union in the case of $8.6 \%$. As from 2006 , this percentage was only about $2 \%$ of companies, and in the years 2011-2017 this level was below $2 \%$, i.e. in the case of every fiftieth company. In 2018, the worst situation applied to establishments in the cereal and milling sector (4.9\% of companies in this sector were characterised by the improper sanitary condition), bakeries (3\%), grocer's shops $(2.8 \%)$ and establishments producing natural mineral waters, natural spring waters and table waters $(2.4 \%)($ SSI 2019 , p. 25).

The third element of health safety of food refers to the level of pesticide residues in the production of food, including, in particular, the primary production (raw materials of plant and animal origin). Monitoring pesticide residues in food is coordinated by the European Food Safety Authority (EFSA). As part of the programme implemented in 2018, 91,015 food samples were tested and 12 food products were considered: aubergines, bananas, broccoli, cultivated mushrooms, grapefruits, melons, sweet peppers/peppers, table grapes, wheat grain, extra virgin olive oil, beef fat and hen eggs. The samples were analysed in terms of 177 pesticide residues: 169 in food of plant origin and 21 in food of animal origin (13 pesticide residues were analysed in terms of food of plant and animal origin) (EFSA 2020, pp. 3-4).

In the case of the Polish market, food free from pesticide residues accounted for $70.6 \%, 54.1 \%, 50 \%$ in 2013,2015 and 2018 , respectively, which means that the safety deteriorated by more than 20 p.p. (decrease by $29.2 \%$ ). Therefore, the situation changed radically because over only five years from the level significantly exceeding the EU level of health safety of food, Poland was included in the group of countries with the level below the EU average.

In certain countries, the level of health safety of food measured by the levels of pesticide residues significantly exceeded the average EU level. For example, the percentage of food free from pesticide residues in Slovenia was $98.3 \%$, in Iceland $97.3 \%$, in Latvia $-87.1 \%$, in Ireland $-84.9 \%$. In turn, in Belgium it was only $33.1 \%$, in Spain $-43.1 \%$, in the Czech Republic $-44.4 \%$ and in the Netherlands $-47.7 \%$. 
On average, in $42.3 \%$ of tested samples for the EU/EEC, the level of pesticide residues exceeded the limits of quantification but was below the maximum residue level (MRL) and in 3.1\% of the samples it exceeded the MRL. For Poland, it was $44.7 \%$ and $5.3 \%$ of tested food samples, respectively. Thus, the situation of Poland is, in general, definitely less favourable than three or four years ago. We should only hope that the results of the last period are temporary and the coming years will be better in this regard. The percentage of tested samples with the exceeded MRL is particularly unfavourable for Poland. With 5.3\% of samples and the EU average of 3.1\%, Poland was ranked sixth among the EU/EEC countries. In 2010, it was $1.6 \%$ for the EU and $1.3 \%$ for Poland (EFSA 2020, p. 19, 57, 2013, p. 394).

In general, the health safety of food in Poland has partially deteriorated in recent years which results in the emergence of additional threats to health of residents of the country. In the first instance, it is related to the increased number of batches of food with pesticide residues because, as it results from control of the sanitary (microbiological) condition, the situation in this regard has been stable for several years.

In addition to health, another element of food safety refers to economic security and is characterised by the so-called commercial quality of food products, i.e. the issue of adulterated food and food of lower quality.

\section{Economic quality of food (food adulteration)}

While analysing quality and economic security of food products on the Polish market, a reference point is the so-called commercial quality of agri-food products defined in the Act on commercial quality which includes the following elements: organoleptic characteristics of a food product, its physical and chemical properties and labelling. The reference of the assessment is the so-called producer's declaration which may be an original recipe, a Polish standard or a standard laid down in the (national or international/EU) legislation. Food quality understood in this way defines the so-called economic security of consumers.

The assessment of food quality and safety as well as the assessment of irregularities present in this regard is carried out in the three basic areas. These are:

- organoleptic assessment (taste, smell, colour, appearance, texture of a product, etc.),

- assessment of physical and chemical parameters differentiated according to the group of products (may apply to such parameters as: fat, water, protein, carbohydrates, salt, sugar, humidity, volume, acidity, etc.),

- assessment of labelling of a product.

The organoleptic assessment is an initial assessment of a product. Its results do not usually provide an unambiguous basis for stating food adulteration. Irregularities identified during this assessment can be a consequence of adulteration of a given food product. Only the assessment of physical and chemical parameters and the assessment of labelling determine whether or not a product is adulterated. In fact, irregularities found during the assessment of physical and chemical parameters and of labelling meet the characteristics (properties) of adulterated food. 
In the case of labelling assessment, , according to a detailed analysis of results of individual official controls, the most frequent irregularities are activities classified as food adulteration (on average, 70-80\%) (Kowalczyk 2009, p. 259). At present, food labelling is important in economic, social and consumer terms. A label on a product's packaging is, in fact, a specific certificate of quality. And thus, like each certificate, it is subject to an "audit process", i.e. the act of purchasing and consuming food. In this process, the content of a label is either confirmed or questioned if any irregularities (product defects, adulteration, misleading labelling, etc.) are found.

The analysis of quality and safety of food products has been based on the results of controls carried out by the AFQI in the years 2005-2019. In that period, the AFQI carried out annual controls of 1 thousand to more than 3 thousand food producing establishments. On average, 5-6 thousand food samples were taken for laboratory tests (in 2019, it was 5.2 thousand samples) (AFQI, 2020, p. 22). The Inspection's laboratories carried out, on average, 30-40 thousand determinations of physical and chemical parameters (in 2019 - 28.2 thousand determinations). The results presented are, therefore, a sufficiently reliable source on food safety and adulteration on the Polish market.

\section{Scale of adulteration of food products - synthetic approach}

What is the situation with regard to the quality and safety, including adulteration of food products available on the Polish market? Definitely, the most favourable situation takes place in the area of organoleptic properties of food (Fig. 2). If we ignore the year 2005, where the level of irregularities in this regard was $7.9 \%$, mainly in such groups of products like butter ( $56 \%$ of questioned batches), fish products $(14 \%)$, poultry meat $(11.8 \%)$ and fruit products $(8 \%)$, in the remaining years of the analysed period, it amounted to $1.5 \%$ on average. This means that only every sixtieth product was questioned in this regard (in 2005 it was every twelfth product). This favourable situation deteriorated in 2017 when the Inspection questioned $2.5 \%$ of batches of food in terms of organoleptic properties (more than a twofold increase in relation to 2016).

In the analysed period (2005-2014) $)^{5}$, there was no definite advantage in the level of irregularities of organoleptic characteristics of products according to the origin of raw materials (Fig. 3). More irregularities were recorded in the case of products of plant origin in the period of five years $(2006,2008,2009,2012,2013)$, similarly as in the case of products of animal origin - also five years $(2005,2007,2010,2011,2014)$.

In fact, the organoleptic assessment is an initial stage of checking the authenticity and adulteration of food products. A laboratory test of physical and chemical parameters of food provides an in-depth knowledge. From this point of view, the image of food safety and quality on the Polish market is less favourable. Over the analysed period of 15 years (2005-2019, Fig. 2), irregularities were found in $10.9 \%-17.9 \%$ of controlled batches of food. In addition, we may observe a relatively not much dynamic yet permanent upward trend (13.1\% in 2005 and $14.5 \%$ in 2019).

\footnotetext{
$\overline{{ }^{5} \text { For the years 2005-2019 }}$ - no aggregate data available.
} 


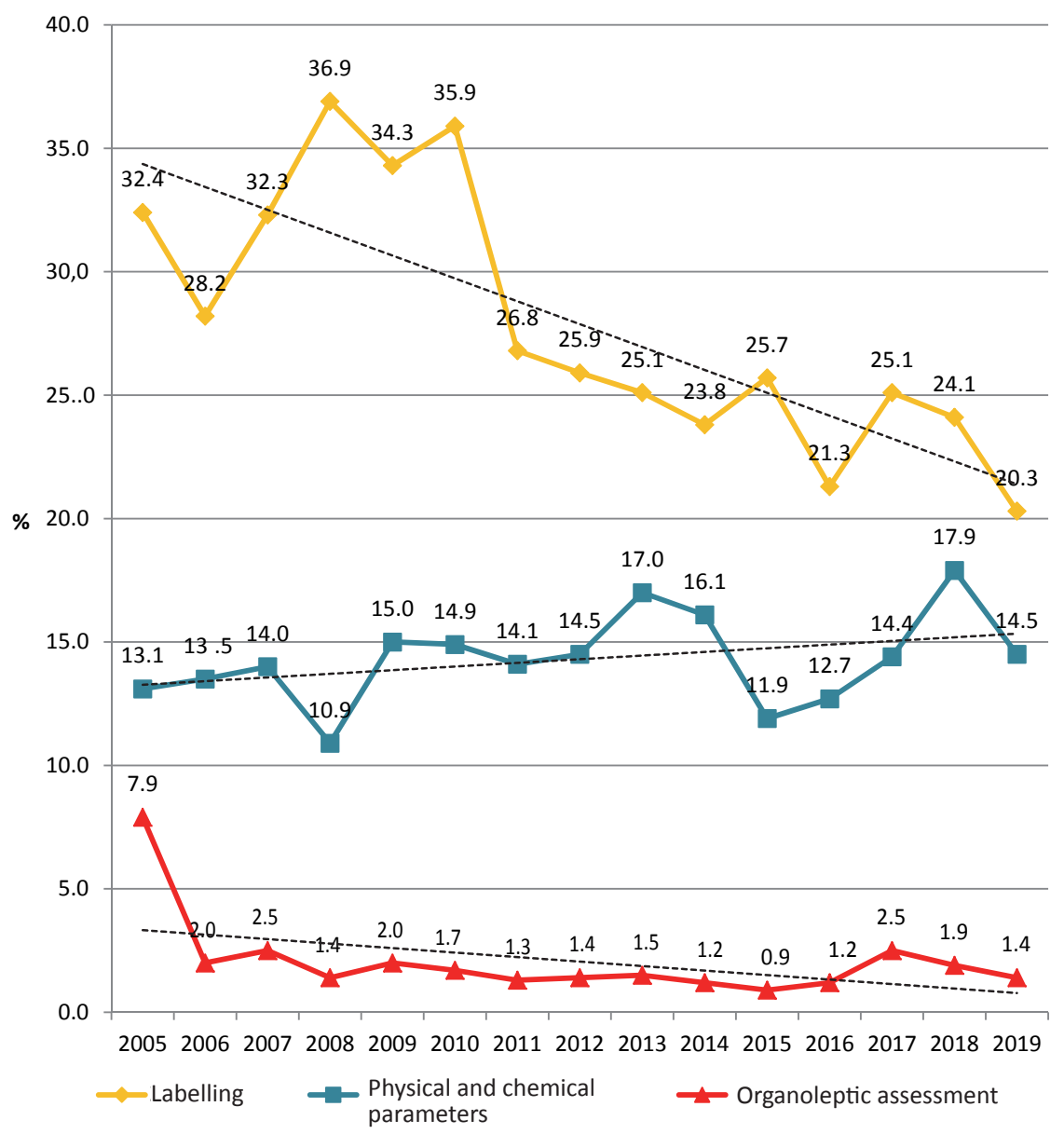

Fig. 2. The percentage of controlled batches of food with irregularities found by individual areas of quality control in the years 2005-2019 (in \%).

Source: own study based on the results of controls carried out by the AFQI in the years 2005-2020.

In the analysed period, the percentage of adulterated batches of animal products was higher (Fig. 4). Here, the scale of irregularities ranged from $11.5 \%$ in 2008 to $18 \%$ in 2013. In seven years of the analysed period (10 years), more irregularities were found in relation to products of animal origin. The percentage of batches of plant products with irregularities found in the assessment of physical and chemical parameters ranged from $10.9 \%$ in 2008 to $19.2 \%$ in 2009 .

In general, the level of quality with regard to physical and chemical parameters of products of plant origin in the total analysed period was higher than that of quality of products of animal origin by about 1.1 p.p. 


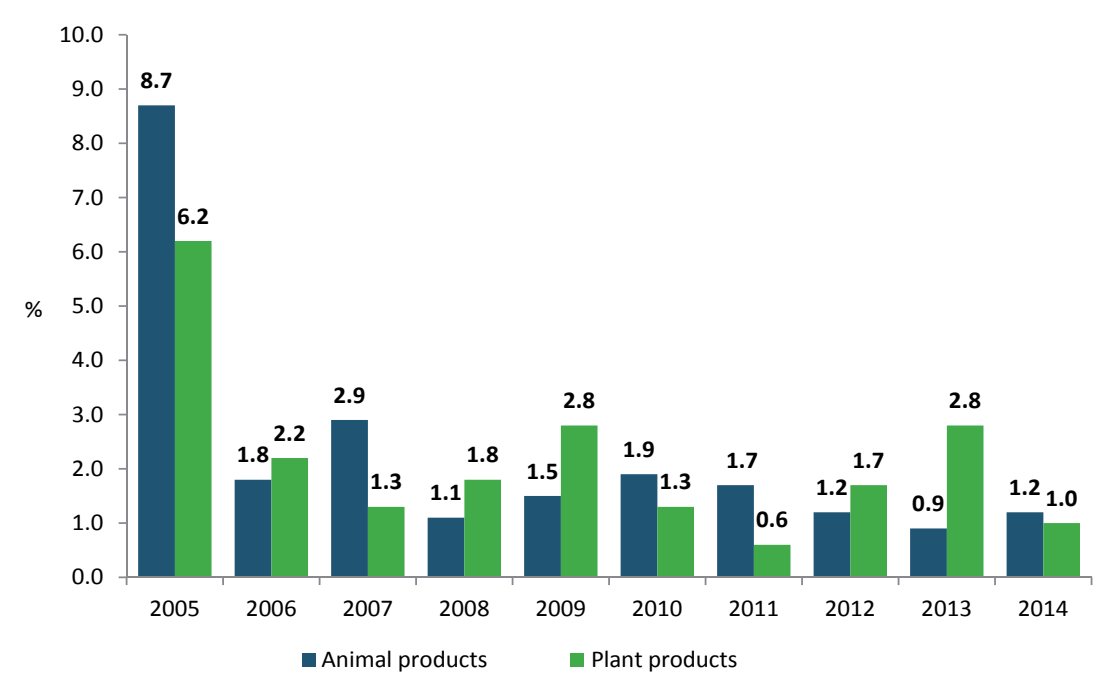

Fig. 3. The percentage of controlled batches of food with irregularities found as part of the organoleptic assessment in the years 2005-2014 (in \%).

Source: own study based on the results of controls carried out by the AFQI in the years 2005-2014.

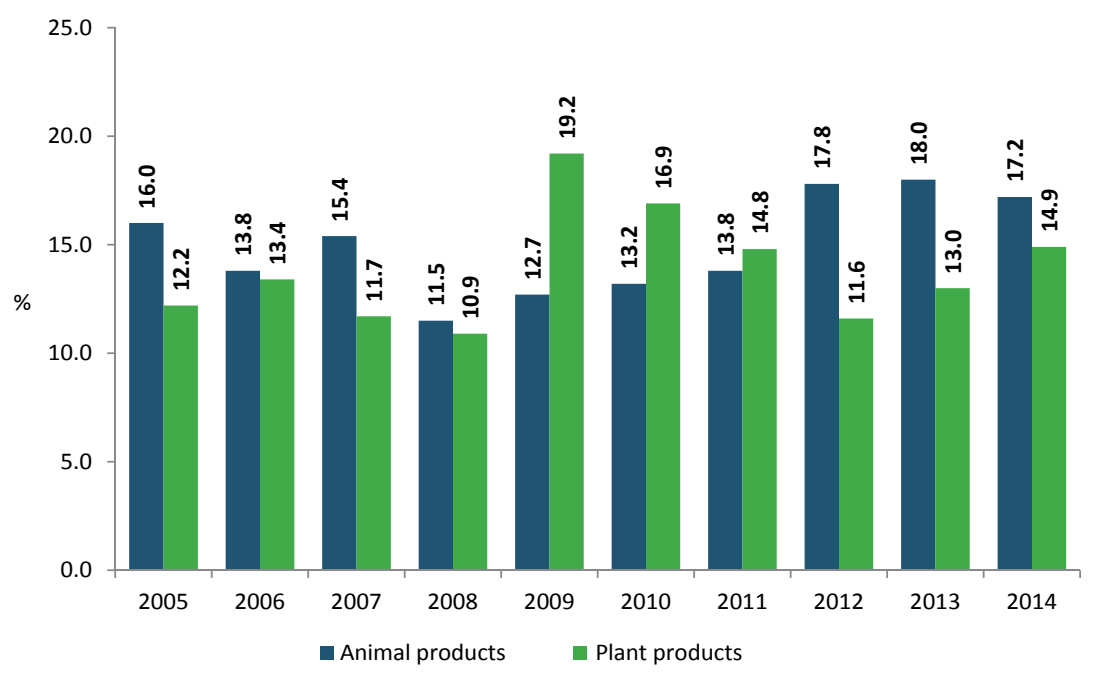

Fig. 4. The percentage of controlled batches of food with irregularities found as part of the assessment of physical and chemical parameters in the years 2005-2014 (in \%).

Source: own study based on the results of controls carried out by the AFQI in the years 2005-2014.

Definitely, the greatest problem and the largest number of irregularities were found in the food labelling process. In the analysed period, the percentage of improperly labelled food ranged from $20.3 \%$ in 2019 to $36.9 \%$ in 2008 (Fig. 2). However, we can clearly see the change in trends in this regard. In the analysed 15 -yearperiod, we can identify at least two periods: 
- first period: years 2005-2010, when the percentage of irregularities in labelling ranged between $28.2 \%$ and $36.9 \%$ which means that it was very high;

- second period: years 2011-2019, when there was a gradual improvement in labelling, while the percentage of improperly labelled batches of food ranged between $20.3 \%$ and $26.8 \%$.

2019 was the most favourable year in this regard, when only every fifth batch of food on the Polish market (20.3\% to be more exact) was improperly labelled. However, it should be stressed that while the level of irregularities of products of plant origin was lower than that of animal products with respect to physical and chemical parameters, in the case of labelling this situation is radically different (Fig. 5). Basically, in the whole analysed period, the labelling of plant products was characterised by more irregularities than that of animal products. This difference amounted to from 0.7 p.p. in 2011 to 9.1 p.p. in 2005.

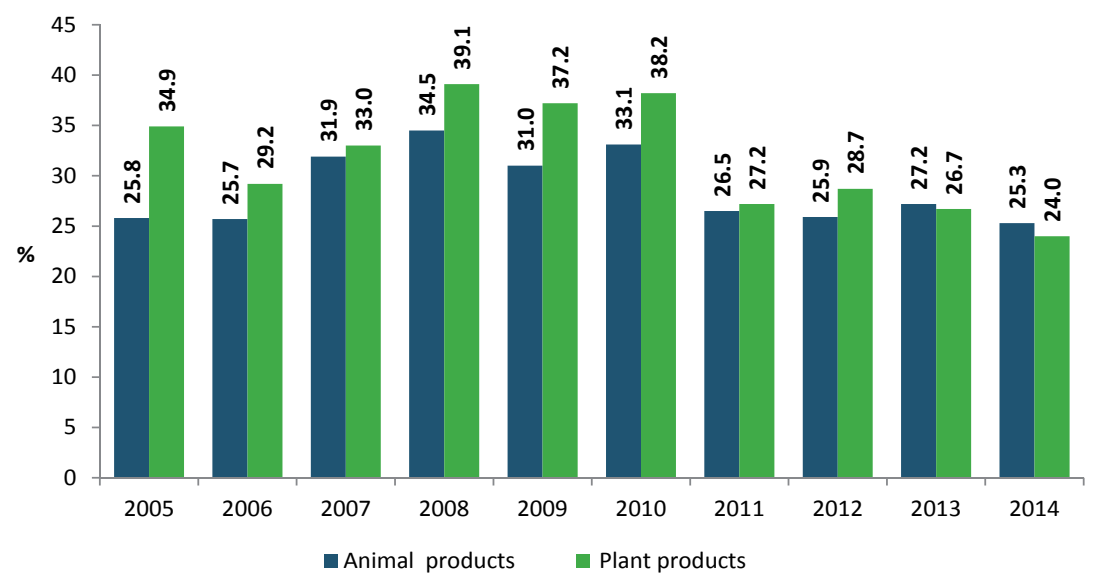

Fig. 5. The percentage of controlled batches of food with irregularities found in labelling in the years 2005-2014 (in \%).

Source: own study based on the results of controls carried out by the AFQI in the years 2005-2014.

\section{Quality and safety by groups of food products}

The quality of food and the level of its adulteration greatly differs in the individual food sectors and product range groups. The analysis by groups of food products shows that the largest number of irregularities with regard to organoleptic characteristics of plant products takes place in relation to products such as: widely understood fruit and vegetable products (in the years 2005-2019, i.e. the period covering fifteen control periods/years, those products were included as many as 12 times in the list of the three most questioned products in terms of organoleptic characteristics), pasta as well as bread and bakery products (11 times). In turn, among products of animal origin these included: milk products (questioned during the 11-year period during 15 analysed years), fish and fish products (8 times) and meat and meat products ( 7 times). 
In the years 2005-2019, the largest number of irregular organoleptic characteristics was shown in the case of the following products and groups of products:

\begin{tabular}{|c|c|c|}
\hline \multirow{2}{*}{ Year } & \multicolumn{2}{|c|}{ Products } \\
\hline & plant & animal \\
\hline 2005 & $\begin{array}{l}\text { sweets }(14.3 \%) \\
\text { food concentrates }(8.3 \%) \\
\text { fruit products }(8.0 \%)\end{array}$ & $\begin{array}{l}\text { butter }(56.0 \%) \\
\text { poultry meat }(17.8 \%) \\
\text { fish and fish products }(14.0 \%)\end{array}$ \\
\hline 2006 & $\begin{array}{l}\text { pasta }(5.6 \%) \\
\text { frozen vegetables }(3.0 \%) \\
\text { bread }(1.2 \%)\end{array}$ & $\begin{array}{l}\text { poultry meat }(4.2 \%) \\
\text { ripened cheese }(4.0 \%) \\
\text { butter }(4.0 \%)\end{array}$ \\
\hline 2007 & $\begin{array}{l}\text { pasta }(3.2 \%) \\
\text { soft drinks }(1.1 \%) \\
\text { bread and breadcrumbs }(0.8 \%)\end{array}$ & $\begin{array}{l}\text { processed cheese }(14.0 \%) \\
\text { poultry meat }(4.2 \%) \\
\text { milk functional products }(4.0 \%)\end{array}$ \\
\hline 2008 & $\begin{array}{l}\text { vegetable products }(7.0 \%) \\
\text { halva and chocolate-coated sweets }(6.1 \%) \\
\text { pasta }(3.5 \%)\end{array}$ & $\begin{array}{l}\text { milk fats }(10.0 \%) \\
\text { milk products }(4.4 \%) \\
\text { cottage cheese }(3.0 \%)\end{array}$ \\
\hline 2009 & $\begin{array}{l}\text { fruit and vegetable products }(7.5 \%) \\
\text { pasta }(6.8 \%) \\
\text { breadcrumbs }(2.7 \%)\end{array}$ & $\begin{array}{l}\text { rennet cheese }(9.1 \%) \\
\text { milk products }(4.9 \%) \\
\text { marinated fish }(2.4 \%)\end{array}$ \\
\hline 2010 & $\begin{array}{l}\text { fruit and vegetable products }(4.9 \%) \\
\text { pasta }(1.9 \%) \\
\text { pastry }(0.7 \%)\end{array}$ & $\begin{array}{l}\text { milk products }(3.4 \%) \\
\text { offal products }(3.3 \%) \\
\text { milk }(2.9 \%)\end{array}$ \\
\hline 2011 & $\begin{array}{l}\text { spices }(2.7 \%) \\
\text { fruit and vegetable products }(1.5 \%) \\
\text { semi-confectionery products }(0.0 \%)\end{array}$ & $\begin{array}{l}\text { butter and rennet cheese }(6.1 \%) \\
\text { poultry meat }(2.3 \%) \\
\text { fish products }(2.0 \%)\end{array}$ \\
\hline 2012 & $\begin{array}{l}\text { spices }(4.5 \%) \\
\text { soft drinks }(3.4 \%) \\
\text { food concentrates }(2.7 \%)\end{array}$ & $\begin{array}{l}\text { cheese, processed cheese }(3.7 \%) \\
\text { poultry meat }(2.9 \%) \\
\text { fish products }(2.0 \%)\end{array}$ \\
\hline 2013 & $\begin{array}{l}\text { pasta }(6.1 \%) \\
\text { fruit products }(2.1 \%) \\
\text { chocolate products }(0.0 \%)\end{array}$ & $\begin{array}{l}\text { eggs }(1.8 \%) \\
\text { poultry products }(1.3 \%) \\
\text { marinated and canned fish }(0.8 \%)\end{array}$ \\
\hline 2014 & $\begin{array}{l}\text { vegetable products }(1.7 \%) \\
\text { frozen fruit and vegetables }(1.0 \%) \\
\text { flours, groats, flakes }(0.4 \%)\end{array}$ & $\begin{array}{l}\text { milk products }(4.4 \%) \\
\text { formed meat and poultry products }(2.2 \%) \\
\text { fish products }(1.9 \%)\end{array}$ \\
\hline 2015 & $\begin{array}{l}\text { wine products }(1.5 \%) \\
\text { bread }(1.0 \%) \\
\text { fruit and vegetable products }(0.9 \%)\end{array}$ & $\begin{array}{l}\text { milk products }(1.9 \%) \\
\text { ready-to-serve products }(1.6 \%) \\
\text { fish products }(1.0 \%)\end{array}$ \\
\hline 2016 & $\begin{array}{l}\text { bread }(11.1 \%) \\
\text { tomato products }(3.6 \%)\end{array}$ & $\begin{array}{l}\text { fat spreads }(10.3 \%) 1 \\
\text { eggs }(2.5 \%)\end{array}$ \\
\hline 2017 & $\begin{array}{l}\text { vegetable oils including olive oil }(20.3 \%) \\
\text { herbs }(12.5 \%) \\
\text { pulses }(10.7 \%) \\
\text { fruit_and vegetable products }(7.8 \%)\end{array}$ & $\begin{array}{l}\text { honey }(3.4 \%) \\
\text { milk products }(1.9 \%) \\
\text { ready-to-serve products }(0.7 \%)\end{array}$ \\
\hline 2018 & $\begin{array}{l}\text { herbs }(16.5 \%) \\
\text { vegetable oils }(15.7 \%) \\
\text { fruit and vegetable products }(3.8 \%)\end{array}$ & $\begin{array}{l}\text { honey }(4.6 \%) \\
\text { ready-to-serve products }(2.7 \%) \\
\text { fish and fish products }(1.4 \%)\end{array}$ \\
\hline 2019 & $\begin{array}{l}\text { olive oil }(52.6 \%) \\
\text { wine products }(2.4 \%) \\
\text { juices and nectars }(1.8 \%)\end{array}$ & $\begin{array}{l}\text { honey }(6.7 \%) \\
\text { ready-to-serve products }(3.5 \%) \\
\text { meat and meat products }(1.8 \%)\end{array}$ \\
\hline
\end{tabular}

The scale of irregularities with regard to organoleptic characteristics of products of plant and animal origin in the analysed period was not equalised: The level of irregularities in products of plant origin was eight times higher while the level of products of animal origin was seven times higher. The level of irregularities 
found was, however, higher among products of animal origin (for example, $56 \%$ of batches of butter in 2005 and 14\% of batches of processed cheese in 2007 were questioned, in the group of products of plant origin the level of questioned batches of olive oil in 2019 was the highest accounting for $52.6 \%$ ).

When examining the level of quality and safety of food products, it must be stated that the situation with regard to meeting the physical and chemical parameters is even worse. Due to the irregularities of those parameters in the years 2005-2019, the most frequently questioned food products included:

\begin{tabular}{|c|c|c|}
\hline \multirow{2}{*}{ Year } & \multicolumn{2}{|c|}{ Products } \\
\hline & plant & animal \\
\hline 2005 & $\begin{array}{l}\text { cereal products }(34.5 \%) \\
\text { breadcrumbs }(34.0 \%) \\
\text { grape wine products }(20.6 \%)\end{array}$ & $\begin{array}{l}\text { butter }(37.0 \%) \\
\text { milk products }(16.0 \%) \\
\text { red meat products }(16.0 \%)\end{array}$ \\
\hline 2006 & $\begin{array}{l}\text { breadcrumbs }(40.0 \%) \\
\text { cereal products }(31.1 \%) \\
\text { concentrated juices }(25.0 \%)\end{array}$ & $\begin{array}{l}\text { fish products }(35.3 \%) \\
\text { probiotics }(22.0 \%) \\
\text { milk products }(20.0 \%)\end{array}$ \\
\hline 2007 & $\begin{array}{l}\text { vinegar }(28.6 \%) \\
\text { soft drinks }(25.9 \%) \\
\text { cereal products }(21.2 \%)\end{array}$ & $\begin{array}{l}\text { frozen fish }(35.0 \%) \\
\text { processed cheese }(30.0 \%) \\
\text { fish products }(26.0 \%)\end{array}$ \\
\hline 2008 & $\begin{array}{l}\text { vegetable products }(18.0 \%) \\
\text { cereal products }(17.4 \%) \\
\text { pasta }(11.3 \%)\end{array}$ & $\begin{array}{l}\text { milk fats }(41.0 \%) \\
\text { pasteurised milk }(38.0 \%) \\
\text { marinated fish }(32.0 \%)\end{array}$ \\
\hline 2009 & $\begin{array}{l}\text { breadcrumbs }(61.9 \%) \\
\text { breadcrumbs }(32.4 \%) \\
\text { flours, groats }(21.5 \%)\end{array}$ & $\begin{array}{l}\text { marinated fish }(52.4 \%) \\
\text { marinated fish }(28.1 \%) \\
\text { milk products }(20.7 \%)\end{array}$ \\
\hline 2010 & $\begin{array}{l}\text { pasta }(28.8 \%) \\
\text { frozen vegetables }(27.1 \%) \\
\text { beer }(23.4 \%)\end{array}$ & $\begin{array}{l}\text { fat spreads }(25.0 \%) \\
\text { fish products }(20.0 \%) \\
\text { milk products }(18.4 \%)\end{array}$ \\
\hline 2011 & $\begin{array}{l}\text { pasta }(27.4 \%) \\
\text { semi-confectionery products }(17.6 \%) \\
\text { dried fruit }(15.6 \%)\end{array}$ & $\begin{array}{l}\text { milk products }(25.0 \%) \\
\text { butter, rennet cheese }(21.3 \%) \\
\text { smoked meat products, dry sausages }(17.9 \%)\end{array}$ \\
\hline 2012 & $\begin{array}{l}\text { soft drinkws }(21.0 \%) \\
\text { beer }(17.2 \%)\end{array}$ & $\begin{array}{l}\text { fat spreads }(40.0 \%) \\
\text { white sausage }(38.0 \%) \\
\text { red meat products }(25.3 \%)\end{array}$ \\
\hline 2013 & $\begin{array}{l}\text { fruit products }(30.1 \%) \\
\text { fermented wine drinks }(24.6 \%) \\
\text { pasta }(18.5 \%)\end{array}$ & $\begin{array}{l}\text { poultry products }(27.2 \%) \\
\text { red meat products }(23.5 \%) \\
\text { milk products }(21.1 \%)\end{array}$ \\
\hline 2014 & $\begin{array}{l}\text { snacks }(19.0 \%) \\
\text { frozen fruit and vegetables }(18.4 \%) \\
\text { bread }(16.7 \%)\end{array}$ & $\begin{array}{l}\text { white sausage pates }(29.5 \%) \\
\text { grill and offal sausage }(20.0 \%) \\
\text { formed meat and poultry products }(17.5 \%)\end{array}$ \\
\hline 2015 & $\begin{array}{l}\text { wine products }(18.7 \%) \\
\text { spices }(14.9 \%) \\
\text { horseradish }(14.3 \%)\end{array}$ & $\begin{array}{l}\text { fish products }(18.4 \%) \\
\text { meat products }(14.5 \%) \\
\text { poultry meat }(12.5 \%)\end{array}$ \\
\hline 2016 & $\begin{array}{l}\text { confectionery }(28.1 \%) \\
\text { beer }(20.6 \%) \\
\text { jams }(20.6 \%)\end{array}$ & $\begin{array}{l}\text { meat products }(20.0 \%) \\
\text { fish products }(17.5 \%) \\
\text { ready-to-serve products }(14.3 \%)\end{array}$ \\
\hline 2017 & $\begin{array}{l}\text { bread }(40.0 \%) \\
\text { fermented wine drinks }(24.0 \%)\end{array}$ & $\begin{array}{l}\text { meat products }(28.1 \%) \\
\text { meat }(20.0 \%) \\
\text { fish and fish products }(14.9 \%)\end{array}$ \\
\hline 2018 & $\begin{array}{l}\text { fruit and vegetable products }(32.1 \%) \\
\text { cereal products }(14.7 \%) \\
\text { beer }(13.3 \%)\end{array}$ & $\begin{array}{l}\text { ready-to-serve products }(32.1 \%) \\
\text { fish and fish products }(28.9 \%) \\
\text { fat spreads }(23.3 \%)\end{array}$ \\
\hline 2019 & $\begin{array}{l}\text { fruit products }(17.7 \%) \\
\text { vegetable products }(14.3 \%) \\
\text { cereal products }(13.2 \%)\end{array}$ & $\begin{array}{l}\text { ready-to-serve products }(27.8 \%) \\
\text { meat and meat products }(23.0 \%) \\
\text { fish products }(19.6 \%)\end{array}$ \\
\hline
\end{tabular}


In the group of products of plant origin, the largest number of irregularities in the area of physical and chemical parameters, i.e. in fact, the lowest level of safety, was observed in products such as: pasta and breadcrumbs (questioned 8 times during the 15-year-period), cereal products ( 8 times), frozen vegetables and vegetable products as well as fruit products ( 8 times). In the product range group including the broadly defined cereal processing products, the number of irregularities, thus also adulteration, was definitely the highest. It is even more essential that these products are a basis of diet of the vast majority of consumers.

In turn, the most adulterated food products of animal origin, in terms of physical and chemical parameters, are red and white meat products (18 times in the list of products with the largest number of physical and chemical irregularities in 15 analytical/control periods), milk products, including butter and milk fats (14 times), fish products such as: frozen and smoked fish, canned and marinated fish (7 times). Therefore, there are three product range groups with a low level of food safety, i.e. meat, milk and fish products. In the list of products with the largest number of irregularities with regard to physical and chemical parameters in the years 2005-2019, $40 \%$ were meat products, $31 \%$ were milk products and $16 \%$ were fish products. It is also worth noting that recent years saw an increase in meat products adulteration in relation to milk and fish products. In the years 2010-2019, out of 30 products of animal origin included in the table meat processing was represented by 17 products $(57 \%)$, milk processing represented by 7 products $(23 \%)$ and fish processing represented by 6 products $(20 \%)$.

In general, with regard to physical and chemical parameters, a slightly higher level of irregularities is represented by products of plant origin in the case of which the highest level of irregularities was observed 8 times, while for products of animal origin it was observed 6 times. The largest number of irregularities with regard to physical and chemical parameters in the whole analysed period was found in the following products: breadcrumbs $(61.9 \%$ in 2009$)$, marinated fish $(52.4 \%$ in 2009 ), milk fats (41\% in 2008), bread (40\% in 2017), fat spreads ( $40 \%$ in 2012 ) and breadcrumbs ( $40 \%$ in 2006).

However, if we ignore breadcrumbs due to its marginal importance in the diet (and distant control periods), it turns out that it is products of animal origin which represent the "stable" high level of irregularities with regard to physical and chemical parameters, mostly milk and meat products.

Definitely, the situation is the worst with respect to food labelling. This is important as, on the one hand, labelling is part of food quality, on the other hand, it is a basic method to inform consumers by producers of characteristics and properties of products. The most frequently questioned food products, in terms of irregularities with regard to labelling, in the years 2005-2019 included: 


\begin{tabular}{|c|c|c|}
\hline \multirow{2}{*}{ Year } & \multicolumn{2}{|c|}{ Products } \\
\hline & plant & animal \\
\hline 2005 & $\begin{array}{l}\text { olive oil }(95.2 \%) \\
\text { bread }(49.8 \%) \\
\text { beer }(47 \%)\end{array}$ & $\begin{array}{l}\text { red meat products }(41 \%) \\
\text { fish products }(35 \%) \\
\text { butter }(24 \%)\end{array}$ \\
\hline 2006 & $\begin{array}{l}\text { pasta }(61.2 \%) \\
\text { fermented wine drinks }(47.6 \%) \\
\text { vegetable products }(46 \%)\end{array}$ & $\begin{array}{l}\text { ready-to-serve products }(48.7 \%) \\
\text { fish products }(40 \%) \\
\text { red meat products }(38 \%)\end{array}$ \\
\hline 2007 & $\begin{array}{l}\text { pasta }(66 \%) \\
\text { vinegar }(53.3 \%) \\
\text { fermented wine drinks }(48.6 \%)\end{array}$ & $\begin{array}{l}\text { frozen fish }(55 \%) \\
\text { butter }(45 \%) \\
\text { red meat products }(44 \%)\end{array}$ \\
\hline 2008 & $\begin{array}{l}\text { halva and chocolate-coated sweets }(55.3 \%) \\
\text { bread }(52.7 \%) \\
\text { bread }(49.2 \%)\end{array}$ & $\begin{array}{l}\text { beef }(58 \%) \\
\text { marinated fish }(54.5 \%) \\
\text { canned fish }(52.6 \%)\end{array}$ \\
\hline 2009 & $\begin{array}{l}\text { breadcrumbs }(80.6 \%) \\
\text { bread }(68.8 \%) \\
\text { breadcrumbs }(56.8 \%)\end{array}$ & $\begin{array}{l}\text { offal cold meats and wiener sausages }(60.5 \%) \\
\text { marinated fish }(56.7 \%) \\
\text { marinated fish }(54.8 \%)\end{array}$ \\
\hline 2010 & $\begin{array}{l}\text { juices, nectars }(74.4 \%) \\
\text { pasta }(51 \%) \\
\text { bakery products }(48.5 \%)\end{array}$ & $\begin{array}{l}\text { fat spreads }(55 \%) \\
\text { offal products (dumplings) }(48.6 \%) \\
\text { medium-minced and formed meat sausages } \\
(46.9 \%)\end{array}$ \\
\hline 2011 & $\begin{array}{l}\text { dried fruit }(59.6 \%) \\
\text { horseradish }(58.8 \%) \\
\text { fruit syrups }(48.1 \%)\end{array}$ & $\begin{array}{l}\text { pates, canned meat }(35.7 \%) \\
\text { smoked meat products }(35 \%) \\
\text { dry and semi-dry sausages }(34.8 \%)\end{array}$ \\
\hline 2012 & $\begin{array}{l}\text { food concentrates }(50.6 \%) \\
\text { mayonnaises and mayonnaise sauces }(44.8 \%) \\
\text { vegetable oils }(40 \%)\end{array}$ & $\begin{array}{l}\text { red meat products }(38.7 \%) \\
\text { red meat products }(35.1 \%) \\
\text { ready-to-serve products }(31.8 \%)\end{array}$ \\
\hline 2013 & $\begin{array}{l}\text { pasta }(47.6 \%) \\
\text { fruit products }(31.9 \%) \\
\text { fermented wine drinks }(29 \%)\end{array}$ & $\begin{array}{l}\text { marinated and canned fish }(42.8 \%) \\
\text { ready-to-serve products }(37.2 \%) \\
\text { red meat products }(34.7 \%)\end{array}$ \\
\hline 2014 & $\begin{array}{l}\text { snacks }(38 \%) \\
\text { olive oil }(37.5 \%) \\
\text { vegetable products }(34.7 \%)\end{array}$ & $\begin{array}{l}\text { grill and offal sausage }(33.9 \%) \\
\text { white sausage and pates }(32.3 \%) \\
\text { smoked meat products and dry sausages }(31.8 \%)\end{array}$ \\
\hline 2015 & $\begin{array}{l}\text { bread }(39.9 \%) \\
\text { soft drinks }(32.3 \%) \\
\text { horseradish }(31.4 \%)\end{array}$ & $\begin{array}{l}\text { ready-to-serve products }(39 \%) \\
\text { fish products }(32.6 \%) \\
\text { mayonnaises and sauces }(29.3 \%)\end{array}$ \\
\hline 2016 & $\begin{array}{l}\text { pasta }(40.9 \%) \\
\text { olive oil }(40 \%) \\
\text { beer }(33.9 \%)\end{array}$ & $\begin{array}{l}\text { ready-to-serve products }(32.2 \%) \\
\text { meat products }(28.5 \%) \\
\text { fish products }(20 \%)\end{array}$ \\
\hline 2017 & $\begin{array}{l}\text { fruit products }(46.5 \%) \\
\text { juices, nectars }(37.7 \%) \\
\text { bread }(30.2 \%)\end{array}$ & $\begin{array}{l}\text { meat products }(40.3 \%) \\
\text { ready-to-serve products }(38.3 \%) \\
\text { honey }(35.9 \%)\end{array}$ \\
\hline 2018 & $\begin{array}{l}\text { beer }(33 \%) \\
\text { bread }(32.3 \%) \\
\text { fruit and vegetable products }(31.1 \%)\end{array}$ & $\begin{array}{l}\text { fat spreads }(53.5 \%) \\
\text { fish and fish products }(38.8 \%) \\
\text { honey }(35.9 \%)\end{array}$ \\
\hline 2019 & $\begin{array}{l}\text { beer }(34.7 \%) \\
\text { juices and nectars }(30.5 \%) \\
\text { olive oil }(30.4 \%)\end{array}$ & $\begin{array}{l}\text { ready-to-serve products }(36.4 \%) \\
\text { honey }(31.8 \%) \\
\text { fish products }(28.4 \%)\end{array}$ \\
\hline
\end{tabular}

In the group of products of plant origin, the largest number of irregularities with regard to labelling, in the 15-year control period, was recorded in the case of: bread and bakery products, including breadcrumbs (questioned 9 times), pasta ( 5 times), fermented wine drinks ( 3 times) and olive oil (4 times). In turn, the most adulterated, 
in terms of labelling, food products of animal origin are: red meat products (questioned 22 times), fish products (12 times), butter and fat spreads (4 times). Interestingly enough, the irregularities in labelling the products of plant origin involved many product ranges, whereas in the case of animal products there was a far-reaching concentration of those irregularities in two groups: meat and fish products. Out of 45 controls of products of animal origin, presented in the above-mentioned table, products of those two groups were the worst in terms of labelling in 32 controls (more than $70 \%$ of controls).

With respect to labelling, a higher level of irregularities is definitely represented by products of plant origin. In the list of three food products, which are the worst in these terms, in the analysed period, plant products were ranked first for as many as 11 control years, while products of animal origin - only three times (in 2008). Products of plant origin are, therefore, labelled worse than those of animal origin, the latter representing, however, worse organoleptic properties and the lower level of physical and chemical parameters.

What can be surprising or rather worrying in the analysis of labelling of food products is the level of these irregularities. In many cases, this level reaches several tens of percent. As it results from the presented control data of 2005-2019, with regard to 90 controls with the largest scope of irregularities, the level of irregularities in labelling exceeded $50 \%$ in the case of as many as 23 controls ( $1 / 4$ of controls). Irregular labelling at the level of at least $1 / 4$ of analysed batches $(25 \%$ and more irregularities) applied to 88 batches of 90 controlled ones. The lowest level of irregularities with respect to labelling was $24 \%$ (control of butter labelling in 2005). This means that in the case of such batches consumers had virtually no chance to buy a properly labelled product. However, what was analysed here were batches with the worst results in terms of food quality and safety on the Polish market, controlled by the AFQI in the years 2005-2019.

\section{Major irregularities with regard to food quality and safety by groups of products}

The scale and methods of food adulteration depend, inter alia, on the specificities of individual food products and the type of applied production technologies and they evolve as the production of food progresses. It may even be concluded that they are being improved. Major types of irregularities are, however, related to several recurrent phenomena ${ }^{6}$ which include:

- lowering the content of the most valuable nutrients;

- replacing more expensive components with cheaper ones (e.g. replacing milk fat with vegetable fat, meat with mechanically separated meat MSM);

- hiding components of low value or even harmful to health, which are important for consumers;

\footnotetext{
${ }^{6}$ More than 100 years ago, this was described by an American pioneer in food testing and creator of the US Food and Drug Administration, H.W. Wiley (Kowalczyk, 2017).
} 
- using unacceptable marketing procedures aimed at making customers believe that a product has properties or characteristics which do not exist in reality (Kowalczyk 2009, p. 271);

- understating net weight.

The above-mentioned irregularities are classified into the group of phenomena typical of food adulteration. They meet the characteristics of adulterated food. The range of "procedures" applied by dishonest producers is, naturally, much more extensive and typical of individual groups of food products. Table 2 presents the most frequent irregularities found during controls carried out by the AFQI in the years 2005-2017 with regard to products or groups of food products.

Table 2

Major irregularities with regard to organoleptic characteristics, physical and chemical parameters and labelling of food products

\begin{tabular}{|c|c|c|c|}
\hline Specification & $\begin{array}{l}\text { Organoleptic } \\
\text { properties }\end{array}$ & $\begin{array}{l}\text { Physical and chemical } \\
\text { parameters }\end{array}$ & Labelling \\
\hline $\begin{array}{l}\text { Fruit } \\
\text { and } \\
\text { vegetable } \\
\text { products }\end{array}$ & $\begin{array}{l}\text { - presence of dead } \\
\text { pests on external } \\
\text { threads of jars; } \\
\text { - taste and smell } \\
\text { of a ready-to-eat } \\
\text { product inconsistent } \\
\text { with the producer's } \\
\text { declaration }\end{array}$ & $\begin{array}{l}\text { - understated net weight; } \\
\text { - overestimated humidity; } \\
\text { - content of a preservative } \\
\text { two times higher in } \\
\text { relation to the producer's } \\
\text { declaration; } \\
\text { - excessive content } \\
\text { of impurities of plant } \\
\text { origin, e.g. cut off tips } \\
\text { of asparagus bean }\end{array}$ & $\begin{array}{l}\text { - groundless extension of the best } \\
\text { before date (without storage tests) } \\
\text { by } 7 \text { months; } \\
\text { - use of an expression } \\
\text { "no preservatives" which is } \\
\text { inconsistent with the applicable } \\
\text { legislation as no additional } \\
\text { substances, including preservatives, } \\
\text { are added to unprocessed food } \\
\text { (frozen fruit and vegetables) }\end{array}$ \\
\hline $\begin{array}{l}\text { Milk } \\
\text { products }\end{array}$ & $\begin{array}{l}\text { improper taste, } \\
\text { of products, non- } \\
\text { uniform colour, eye } \\
\text { formation of cheese, } \\
\text { improper pressing, i.e. } \\
\text { presence of slits and } \\
\text { drops of free water } \\
\text { on the surface; } \\
\text { - floury texture of } \\
\text { semi-liquid products } \\
\text { such as cream and } \\
\text { flavoured cheeses, } \\
\text { as well as foreign } \\
\text { taste and smell } \\
\text { in the case of } \\
\text { cottage cheeses }\end{array}$ & $\begin{array}{l}\text { presence of foreign fats } \\
\text { (e.g. vegetable fats) } \\
\text { and plant sterols; } \\
\text { - excessive content } \\
\text { of water (particularly } \\
\text { in cottage cheeses); } \\
\text { - underestimated content } \\
\text { of protein in most milk } \\
\text { products; } \\
\text { - adulteration of butter } \\
\text { with vegetable fats; } \\
\text { - understated net weight; } \\
\text { - excessive freezing point } \\
\text { of water (pasteurised } \\
\text { milk); } \\
\text { - presence of cow's milk } \\
\text { in sheep cheese. }\end{array}$ & $\begin{array}{l}\text { provision of the expiry date longer } \\
\text { than in the declared norm; } \\
\text { - no specification of all ingredients } \\
\text { used for the production e.g. } \\
\text { calcium chloride; } \\
\text { - provision of information } \\
\text { on the quality grade, i.e. grade } \\
\text { I in labelling of a product for } \\
\text { which the producer, in the quality } \\
\text { specification, does not provide } \\
\text { for quality grades of this product; } \\
\text { - provision of ingredients which are } \\
\text { not actually used for the production } \\
\text { and emphasizing them in a graphic } \\
\text { design (fruit, vegetables). }\end{array}$ \\
\hline
\end{tabular}


cont. Table 2

\begin{tabular}{|c|c|c|c|}
\hline Specification & $\begin{array}{l}\text { Organoleptic } \\
\text { properties }\end{array}$ & $\begin{array}{l}\text { Physical and chemical } \\
\text { parameters }\end{array}$ & Labelling \\
\hline $\begin{array}{l}\text { Red meat } \\
\text { products }\end{array}$ & $\begin{array}{l}\text { - improper appearance } \\
\text { of the cross section, } \\
\text { i.e. slithery surface } \\
\text { and altered colour } \\
\text { of the cross section; } \\
\text { - improper smell }\end{array}$ & $\begin{array}{l}\text { - presence of undeclared } \\
\text { raw materials, including } \\
\text { MSM (up to 64\% of } \\
\text { raw material of poultry } \\
\text { origin, up to } 58 \% \text { of raw } \\
\text { material of beef origin) } \\
\text { in a product declared } \\
\text { as a pork product; } \\
\text { - presence of bone } \\
\text { particles; } \\
\text { - excessive content } \\
\text { of water, fat and salt } \\
\text { (water - up to } 16 \text { p.p., } \\
\text { fat up to } 10 \text { p.p., salt } \\
\text { up to } 2 \text { p.p.); } \\
\text { - underestimated content } \\
\text { of protein (up to } 10 \text { p.p.); } \\
\text { - presence of undeclared } \\
\text { nitrates/nitrites and } \\
\text { phosphates. }\end{array}$ & $\begin{array}{l}\text { - lack of all raw materials used } \\
\text { in the production process, e.g. } \\
\text { mechanically separated poultry } \\
\text { meat (MSM), smoke aromas, } \\
\text { water, pork rinds, starch, yeast } \\
\text { extract, pork fat, flavour enhancers, } \\
\text { thickening agents; } \\
\text { - provision of information } \\
\text { misleading consumers i.e. } \\
\text { 1) as to the type of a product: } \\
\text { the trade name "ham" was used } \\
\text { for a product with a finely minced } \\
\text { meat and pork raw material with } \\
\text { the content of pork ham at the level } \\
\text { of 50\% or the name "ham - finely } \\
\text { minced product" was used for } \\
\text { a formed meat product; } \\
\text { 2) as to production methods, } \\
\text { for example, the following } \\
\text { designations were used: traditional, } \\
\text { home-made, rural, tradition and } \\
\text { taste, traditional taste, while there } \\
\text { are no documents confirming } \\
\text { traditional production methods } \\
\text { and smoke aromas, monosodium } \\
\text { glutamate, mechanically separated } \\
\text { meat (MSM), soy protein } \\
\text { concentrate, etc. were used. }\end{array}$ \\
\hline $\begin{array}{l}\text { Poultry } \\
\text { products }\end{array}$ & & $\begin{array}{l}\text { presence of undeclared } \\
\text { pork raw materials } \\
\text { (up to } 44 \text { p.p. } \\
\text { of the composition); } \\
\text { - presence of undeclared } \\
\text { starch, soy raw materials, } \\
\text { phosphates; } \\
\text { - excessive content of } \\
\text { water and soil in relation } \\
\text { to the producer's declara- } \\
\text { tion (water up to } 25 \text { p.p., } \\
\text { salt up to } 2 \text { p.p.) } \\
\text { - underestimated content } \\
\text { of protein (up to } 15 \text { p.p.). }\end{array}$ & $\begin{array}{l}\text { in the production process, e.g. } \\
\text { water, aromas, MSM, flavour } \\
\text { enhancers and thickening agents; } \\
\text { - use of the name of a product which } \\
\text { misleads consumers, e.g. poultry } \\
\text { loin (name of a product typical } \\
\text { of pork), old-Polish style chicken -- } \\
\text { the name suggests that a product is } \\
\text { made of poultry raw materials only } \\
\text { while also pork raw materials were } \\
\text { used for the production. }\end{array}$ \\
\hline
\end{tabular}

Source: Kowalczyk, 2016.

\section{Food quality schemes}

One of the methods to pursue the EU food quality policy is to grant designations confirming high quality of agricultural products and food products originating in specific regions and characterised by the traditional production method (Kwasek, 2011). The European quality scheme has identified two essential categories of products: traditional products and regional products. Traditional products are granted 
the Traditional Specialities Guaranteed (TSG) designation while regional products identified by the Protected Designation of Origin (PDO) or Protected Geographical Indication (PGI) designations.

Polish products are submitted for registration with the European Commission pursuant to the Act of 17 December 2004 on the registration and protection of names and designations of agricultural products and food products and on traditional products. The total number of products with registered geographical names (PDO, PGI) and TSG in Poland is 47 (43 - food and 4 - spirits) (Table 3). The increased number of traditional and regional products with registered geographical names is translated into the level of their consumption7.

In recent years, the interest of consumers in regional and traditional products has been growing. We can observe the dynamic increase in this group of products, as illustrated by the list of their total number, i.e. agri-food products, wines, aromatised wines and spirits registered in the EU countries in the years 1996-2018 (Table 4). In the analysed period, there has been a fourfold increase in the number of products with PGI and PDO. It is definitely higher in the group of agri-food products where in the analysed period the number of registered products increased 4.9 times while in the group of wines - 3.3 times. The increase in the number of spirits was much slower and, in turn, as a consequence of new legal regulations aimed at organising the market of spirits, the number of registered products in this category in the years 2010-2018 decreased by 19.9\% (Kowalczyk, Krzyżanowski and Kwasek, 2018).

In Poland, the market of products with registered PDO, PGI and TSG names is small. The situation of the sector is best illustrated by the fact that its share in the value of the total Polish market of food products and drinks is below $1 \%$. Products are most often sold directly on a farm or in the producer's processing plant, in local sales points, in marketplaces and bazaars, without appropriate marketing support and are promoted only by occasionally organised "festivals of taste" and events promoting regions, national traditions or those related to ecology. Nevertheless, traditional and regional food has a great economic potential. Broadening the market offer of protected products and taking efficient marketing measures on a greater scale will eliminate dishonest producers from the market and create a barrier to potential new actors of this kind (Rejman, Halicka and Nagalska, 2015).

\footnotetext{
${ }^{7}$ In the European Union countries, the sales value of those products rose from EUR 48.4 billion in 2005 to EUR 54.3 billion in 2010, i.e. by $12.2 \%$. The fastest increase involved the sale of agricultural and food products (by 18.9\%), followed by spirits (by 13.7\%) and wines (by 8.6\%). The sale of aromatised wines remained at the same level (AND International, 2012).
} 
Table 3

List of Polish traditional and regional products registered in the European Union (as of 12.05.2020)

\begin{tabular}{|c|c|c|}
\hline $\begin{array}{l}\text { Protected Designation } \\
\text { of Origin (PDO) }\end{array}$ & $\begin{array}{l}\text { Protected Geographical } \\
\text { Indication (PGI) }\end{array}$ & $\begin{array}{l}\text { Traditional Specialities } \\
\text { Guaranteed (TSG) }\end{array}$ \\
\hline \multirow{6}{*}{$\begin{array}{l}\text { Miód z Sejneńszczyzny/ } \\
\text { Łoździejszczyznya } \\
\text { Fasola wrzawska } \\
\text { Fasola Piękny Jaś z Doliny } \\
\text { Dunajca/Fasola z Doliny } \\
\text { Dunajca }\end{array}$} & Czosnek galicyjski & \multirow{2}{*}{$\begin{array}{l}\text { Kiełbasa krakowska sucha } \\
\text { staropolska }\end{array}$} \\
\hline & Kiełbasa piaszczańska & \\
\hline & \multirow{2}{*}{$\begin{array}{l}\text { Kiełbasa biała parzona } \\
\text { wielkopolska }\end{array}$} & \multirow{2}{*}{$\begin{array}{l}\text { Kabanosy staropolskie } \\
\text { Kiełbasa myśliwska staropolska }\end{array}$} \\
\hline & & \\
\hline & Krupnioki śląskie & Kiełbasa jałowcowa staropolska \\
\hline & Cebularz lubelski & \multirow{4}{*}{$\begin{array}{l}\text { Pierekaczewnik } \\
\text { Olej rydzowy tradycyjny } \\
\text { Czwórniak staropolski } \\
\text { tradycyjny }\end{array}$} \\
\hline \multirow{2}{*}{$\begin{array}{l}\text { Karp zatorski } \\
\text { Podkarpacki miód } \\
\text { spadziowy }\end{array}$} & Jagnięcina podhalańska & \\
\hline & Ser koryciński swojski & \\
\hline \multirow{17}{*}{$\begin{array}{l}\text { Wiśnia nadwiślańska } \\
\text { Redykołka } \\
\text { Oscypek } \\
\text { Bryndza podhalańska }\end{array}$} & Jabłka grójeckie & \\
\hline & Kołocz śląski/kołacz śląski & \multirow{16}{*}{$\begin{array}{l}\text { Trójniak staropolski tradycyjny } \\
\text { Dwójniak staropolski tradycyjny } \\
\text { Półtorak staropolski tradycyjny }\end{array}$} \\
\hline & Miód drahimski & \\
\hline & Chleb prądnicki & \\
\hline & Jabłka łąckie & \\
\hline & Śliwka szydłowska & \\
\hline & Obwarzanek krakowski & \\
\hline & Kiełbasa lisiecka & \\
\hline & Suska sechlońska & \\
\hline & Miód kurpiowski & \\
\hline & Fasola korczyńska & \\
\hline & Truskawka kaszubska & \\
\hline & Andruty kaliskie & \\
\hline & Wielkopolski ser smażony & \\
\hline & Rogal świętomarciński & \\
\hline & $\begin{array}{l}\text { Miód wrzosowy z Borów } \\
\text { Dolnośląskich }\end{array}$ & \\
\hline & Podpiwek kujawski & \\
\hline
\end{tabular}

${ }^{a}$ a cross-border application submitted together with Lithuania

Source: own study based on the DOOR - Database of Origin and Registration (http://ec.europa.eu/agriculture). 
Table 4

Number of regional and traditional products in the EU in the years 1996-2018

\begin{tabular}{lrrrrr}
\hline \multicolumn{1}{c}{ Products } & \multicolumn{1}{c}{1996} & 2006 & 2010 & 2017 & \multicolumn{1}{c}{2018} \\
\hline Total & 1,004 & 1,850 & 2,768 & 3,373 & 4,106 \\
Agri-food & 332 & 673 & 867 & 1,363 & 1,624 \\
Wines & 672 & 1,177 & 1,560 & 1,758 & 2,207 \\
Aromatised wines & - & & 4 & 5 & 5 \\
Spirits & - & & 337 & 247 & 270 \\
\hline
\end{tabular}

Source: own study based on (Qualivita, 2017; AND International, 2012; Nathon, 2018).

\section{Summary}

The analysis of the quality of food products on the Polish market, carried out based on several thousand controls, indicates the significant scale of food adulteration and the presence of low-quality products. The smallest number of critical remarks applies to organoleptic properties of food products. In this regard, only about $1-1.5 \%$ of all batches had specific defects and this trend has not considerably deteriorated since 2009/2010. The situation with physical and chemical parameters declared by enterprises is even much worse. In this case, the level of irregularities has oscillated for years around $15 \%$ of batches with irregularities. What may be even more worrying is the fact that recently the percentage of such batches has been slowly yet steadily growing and in the years 2015-2019: it increased from 11.9 to $14.5 \%$. This means that, on average, every seventh controlled batch shows specific deviations from the level declared by producers.

As regards labelling of food products, for many years the scale of irregularities and adulteration has been the largest in this respect. Recently, there has been a significant improvement in this regard and while in the years 2008-2010 the level of irregularities in food labelling was about 35\%, in the years 2011-2014 it decreased to the level of $25-27 \%$. In 2016, it was even $21.3 \%$ but in the following year this level was higher than $25 \%$ again. In 2019 , it was $20.3 \%$. However, it is difficult to forecast what trend will dominate in the coming years.

The level of food safety on the Polish market is good and comparable to other EU countries. This concerns in the first place health safety of food and economic security, although to a smaller extent. The level of irregularities, including food adulteration is relatively high and, unfortunately, "stable". For many years, irregularities with regard to physical and chemical parameters have been maintained at the level of $15 \%$, while the percentage of improperly labelled batches of food has been decreasing. The state of economic security of the Polish food market requires active measures on the part of official food control institutions, which, however, would need significant financial and staff support. This demand becomes all the more important in the face of planned new market initiatives, like, for example, the Food 
Platform. One of the conditions of its success is, in fact, full transparency which, first of all, would apply to marketing standards and quality of products being traded.

In general, the above-mentioned situation requires decisive remedial measures. This significant amount of adulterated and low quality food is equal to the high risk to consumers. This risk refers to health safety to a smaller extent and to economic security to a much higher extent. It is a consequence of non-equivalent trade, resulting from exposure to adulterated food, which means acquiring food whose value is below the value declared by the producer/seller for a specific amount of money. To counteract this situation, we may use methods with a varying scope of action and varying efficiency. The first and fundamental condition of efficient safety systems is efficient food law. Efficient food law is all the more important as the individual consumer has no causative power to shape it, whereas it protects all regardless of the unit market power of consumers.

Another method to counteract efficiently is to build strong structures of entities forming official food control. These systems are created virtually in each country and, however, even in the richest ones, such as the USA, their efficiency is insufficient and, as a consequence, in the USA about 48 million consumers a year are victims of consuming defective, contaminated and low quality food (Johnson, 2016 , p. 1). The efficiency of safety systems may be ensured not only by additional financial and human resources but, first of all, by efficient cooperation of all stakeholders, i.e. governmental institutions, entrepreneurs, consumer organisations, academic centres, educational and advisory organisations etc. Only this kind of chain for safety may be effective in combating irregularities with regard to food quality and safety.

For these reasons, measures with regard to educating consumers, empowering consumer organisations or promoting partner forms of market activity are also important.

Possible methods to eliminate adulterated and low quality food should also include the promotion of food quality schemes, including those for regional and traditional food. Food quality schemes are an additional guarantee of quality defined according to criteria adopted in these schemes, including the nutritive value, taste, but, first of all, food safety and freedom from adulteration and contamination.

Quality schemes are inextricably linked with another method to limit irregularities in the food market, i.e. promotion of short food chains. These chains bring specific benefits both to producers (including farmers) and to consumers. Producers gain additional income, mainly in the form of acquiring part of value added implemented in long chains by other cells. Consumers gain access to high quality food, information about its producers, finally, often to food much cheaper than in large retail chains. Direct and frequent contact between the first manufacturing cell and the consumer definitely reduces inclination to adulterate food, sell stale, contaminated or poisoned food.

Finally, we should stress the importance of international cooperation, both at the level of official control institutions and consumer organisations. Globalisation cre- 
ated a platform for simply unlimited trade in food products, but also for importing food fraud. This conclusion is illustrated and confirmed by, inter alia, the results of controls of one of imported products, i.e. olive oil, where the level of irregularities with regard to labelling has amounted to $30-40 \%$ in recent years.

The above-mentioned methods to improve the state of food safety, naturally, do not mean that the catalogue of potential activities is complete. They only point to areas which, after analysing shortcomings of the modern global food market and its state and related risk, are or may be deemed important for safety of food and thus of consumers. 


\section{References}

Act dated 25 August 2006 on food and nutrition safety, Journal of Laws Dz.U. 2006, No. 171, item 1225 .

AND International (2012). Value of Production of Agricultural Products and Foodstuffs, Wines, Aromatised Wines and Spirits Protected by a Geographical Indication (Gi). Final Report.

Database of Origin and Registration. Retrieved from: http:/ec.europa.eu/agriculture.

EFSA (2020). The 2018 European Union Report on Pesticide Residues in Food, Scientific Report of EFSA. EFSA Journal, 18(4):6057.

EFSA (2013). The 2010 European Union Report on Pesticide Residues in Food, Scientific Report of EFSA. EFSA Journal, 11(3):3130.

IJHARS (2006). Sprawozdanie roczne 2005. Warszawa.

IJHARS (2008). Sprawozdanie roczne 2007. Warszawa.

IJHARS (2010). Sprawozdanie roczne 2009. Warszawa.

IJHARS (2012). Sprawozdanie roczne 2011. Warszawa.

IJHARS (2014). Sprawozdanie roczne 2012. Warszawa.

IJHARS (2016). Sprawozdanie roczne 2015. Warszawa.

IJHARS (2018). Sprawozdanie roczne 2017. Warszawa.

IJHARS (2020). Sprawozdanie roczne 2019. Warszawa.

Johnson, R. (2016). The Federal Food Safety System, Congressional Research Service, December 16. Retrieved from: https://www.fas.org/sgp/crs/misc/RS22600.pdf (access date: 02.06.2020).

Kowalczyk, S. (2016). Bezpieczeństwo i jakość żywności. Warszawa: Wydawnictwo Naukowe PWN.

Kowalczyk, S. (2017). Prawo czystej żywności. Od Kodeksu Hammurabiego do Codex Alimentarius. $2^{\text {nd }}$ Ed. Warszawa: Szkoła Główna Handlowa.

Kowalczyk, S., Krzyżanowski, J., Kwasek, M. (2018). Z badań nad rolnictwem społecznie zrów-noważonym (47). Zrównoważone systemy żywnościowe. M. Kwasek (ed.). Monografie Programu Wieloletniego 2015-2019, No. 83. Warszawa: IERiGŻ-PIB.

Kowalczyk, S. (ed.). (2009). Bezpieczeństwo żywności w erze globalizacji. Warszawa: Szkoła Główna Handlowa.

Kwasek, M. (2011). Jakość i bezpieczeństwo żywności. In: M. Kwasek (ed.) Z badań nad rolnictwem społecznie zrównoważonym (13). Jakość i bezpieczeństwo żywności a zdrowie konsumenta (pp. 17-30). Program Wieloletni 2011-2014, No. 8. Warszawa: IERiGŻ-PIB.

Nathon, N. (2018). Geographical Indications in the EU. European Commission. Tel Aviv.

Notice of the Speaker of the Sejm of the Republic of Poland dated 8 November 2017 on publication of the consolidated text of the Act on commercial quality of agri-food products (Joural of Laws Dz.U. 2017, item 2212).

PIS (2006). Stan sanitarny kraju w roku 2005. Warszawa.

PIS (2008). Stan sanitarny kraju w roku 2007. Warszawa.

PIS (2010). Stan sanitarny kraju w roku 2009. Warszawa.

PIS (2011). Stan sanitarny kraju w roku 2010. Warszawa.

PIS (2013). Stan sanitarny kraju w roku 2012. Warszawa.

PIS (2015). Stan sanitarny kraju w roku 2014. Warszawa.

PIS (2017). Stan sanitarny kraju w roku 2016. Warszawa.

PIS (2019). Stan sanitarny kraju w roku 2018. Warszawa. 
Qualivita (2017). Food \& Wine Products with Geographical Indication. The European GI System, the Italian model and the Case of Aceto Balsamico di Modena PGI. Siena.

Rejman, K., Halicka, E., Nagalska, H. (2015). Szanse polskiego rynku żywności tradycyjnej i regionalnej a zachowania konsumentów. Wieś i Rolnictwo, No. 3(168), pp. 117-132. 


\title{
JAKOŚĆ ŻYWNOŚCI NA POLSKIM RYNKU - ZAGROŻENIA I SPOSOBY ICH ELIMINACJI
}

\begin{abstract}
Artykuł poświęcony jest zagadnieniu dotyczacemu jakości żywności na polskim rynku, identyfikacji zagrożeń oraz sposobów ich eliminacji. We współczesnym świecie kwestia jakości oraz powiazanego z nia bezpieczeństwa żywności jest przedmiotem szczególnej troski państw i organizacji międzynarodowych. Brak odpowiednich rozwiązań instytucjonalnych stwarza ryzyko wystapienia w obrocie żywności negatywnych skutków dla zdrowia lub życia człowieka. Rozpoznanie obszarów zagrożeń w całym łańcuchu żywnościowym, czyli od produkcji pierwotnej przez przetwarzanie, magazynowanie, dystrybucje, sprzedaż produktów żywnościowych aż do konsumpcji, stanowi podstawe zapewnienia bezpieczeństwa żywności. Na podstawie rzeczywistych wyników kontroli instytucji powołanych do sprawowania urzędowego nadzoru nad żywnościa, przedstawiono stan bezpieczeństwa zdrowotnego i ekonomicznego (skala nieprawidłowości i zafatszowań) żywności na rynku krajowym.
\end{abstract}

Słowa kluczowe: jakość żywności, fałszowanie żywności, systemy jakości żywności.

Accepted for print: 30.09 .2020$.

Unless stated otherwise all the materials on the website are available under the Creative Commons Attribution 4.0 International license.

Some rights reserved to the Institute of Agricultural and Food Economics - National Research Institute.

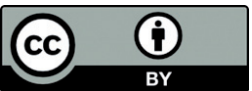

